\title{
PEMBERITAAN TIRTO.ID TENTANG KEKERASAN DI PAPUA: ANALISIS WACANA KRITIS TEUN VAN DIJK
}

\author{
Nur Wahyudi ${ }^{1)}$, Dadang S. Anshori ${ }^{2)}$, Jatmika Nurhadi ${ }^{3)}$ \\ 1,2,3 FPBS, Universitas Pendidikan Indonesia \\ pos-el: nurwahyudi@upi.edu,dadanganshori@upi.edu,jatmikanurhadi@upi.edu
}

\begin{abstract}
Abstrak
Media massa memiliki peran yang sangat besar dalam menyebarkan informasi dan berita. Namun, media massa ini juga dapat dimanfaatkan oleh pihak-pihak tertentu untuk membentuk pemahaman atau ideologi bagi masyarakat. Oleh karena itu, media massa dikatakan tidak netral dan masih menggandeng pihak-pihak tertentu. Informasi tentang Papua masih dibatasi oleh mereka yang memiliki kekuasaan, maka masyarakat Indonesia pada umumnya tidak mengetahui apa yang terjadi di Papua dan sebaliknya, masyarakat Papua tidak mengetahui informasi tentang dunia luar. Penelitian ini akan membahas pemberitaan Tirto.id yang berjudul "Rekaman Kekerasan di Papua". Penelitian ini dilakukan dengan menggunakan pisau analisis wacana kritis model Teun A. Van Dijk. Metode yang digunakan adalah deskriptif kualitatif. Objek penelitian ini berupa kata, frasa, kalimat atau wacana dalam berita "Rekaman Kekerasan di Papua". Teknik pengumpulan data menggunakan teknik observasi dan teknik catat. Teknik analisis data menggunakan model Miles dan Huberman. Hasil penelitian ini menunjukkan bahwa analisis struktur teks yang dilakukan pada teks berita "Rekaman Kekerasan di Papua" sesuai dengan tiga struktur model analisis wacana Teun A. Van Dijk.

Kata kunci: Analisis Wacana Kritis, Struktur Makro, Struktur Mikro, Struktur Super
\end{abstract}

\begin{abstract}
The mass media has a very big role in spreading information and news. However, this mass media can also be used by certain parties to form an understanding or ideology for the public. Therefore, the mass media is said to be not neutral and still takes with certain parties. Information abaot Papua is still limited by those who have power, then the Indonesian people in general do not know what is happening in Papua and vice verse, the Papuan people do not know informaiton about the outside world. This research will discuss the Tirto.id news entitled "Recording Violence in Papua". This research was conducted using rhe critical discourse analysis knife of the Teun A. Van Dijk model. The method used is descriptive qualitative. The object of this research is a word, phrase, sentence or discourses in the news "Recording Violence in Papua". The data collection technique used the observation technique and note-taking technique. The data analysis technique used the Miles and Huberman model. The results of this study indicate that the text structure analysis carried out on the news text "Recording Violence in Papua" is in according with the three structures of discourse analysis model Teun A. Van Dijk.
\end{abstract}

Keywords: Critical Discourse Analysis, Macro Structure, Micro Structure, Super Structure. 


\section{PENDAHULUAN}

Perkembangan teknologi dan informasi menjadi sebuah fenomena yang tidak dapat dihindari. Media massa memiliki peran yang sangat besar dalam kehidupan bermasyarakat seperti mengabarkan berbagai berita di setiap daerah. Media massa itu bisa dapat berupa surat kabar, majalah, radio, televisi dan film. Ditambah lagi dengan munculnya media-media online yang dapat diakses dengan mudah. Media massa itu sudah menjadi sebuah pemenuh kebutuhan akan informasi sejak mulai berkembangnya media massa itu sendiri. Informasi dapat dijadikan sebuah kekuatan oleh pihak tertentu dengan tujuan tertentu.

Dalam kaitannya sebagai institusi pemroduksi dan penyebar informasi, media menjadi sarana yang sangat strategis bagi pihak tertentu untuk membentuk sebuah opini publik yang mencerminkan paham tertentu. Sebuah paham ideologi dapat dimapankan melalui media, entah itu paham yang baik atau buruk (Eriyanto, 2011). Kemudian, berita yang disebar oleh media pada dasarnya tidak persis sama dengan fakta peristiwa, tetapi merupakan sebuah rekonstruksi realitas yang dibuat sesuai dengan kepentingan yang diinginkan sebuah pihak. Sehingga media itu bukan sarana yang netral yang menyampaikan fakta apa adanya kepada publik.

Untuk melihat sebuah ideologi yang sengaja ditanamkan oleh media tertentu, bahasa dapat menjadi unsur penting untuk membongkar ideologi sebuah media. Berita yang dimuat oleh media bukanlah representasi dari peristiwa semanta-mata, tetapi di dalamnya memuat nilai-nilai lembaga media yang membuatnya (Darma, 2009). Maka dari itu, penelitian ini akan menggunakan analisis wacana kritis. Kridalaksana (2013:259) berpendapat bahwa wacana adalah satuan paling lengkap dalam hierarki gramatikal tertinggi atau terbesar. Selanjutnya dijelaskan bahwa sebagai satuan bahasa yang lengkap, maka dalam wacana tersebut terdapat konsep, gagasan, pikiran atau ide yang utuh, sehingga bisa dipahami oleh pembaca (dalam tulisan) atau pendengar (dalam lisan). Karena memakai persepektif kritis, analisis wacana kategori ini disebut sebagai analisis wacana kritis.

Analisis wacana kritis menurut Darma (2009:49) adalah sebuah usaha atau proses penguraian untuk memberi sebuah penjelasan dari sebuah teks 
Nur Wahyudi, Dadang S Anshori, Jatmika Nurhadi...

(realitas sosial) yang mau atau sedang diteliti oleh seseorang atau kelompok dominan yang kecenderungannya mempunyai tujuan tertentu untuk memperoleh apa yang diinginkan. Sedangkan Lukman (2006:12) berpendapat bahwa analisis wacana kritis bekerja lebih jauh daripada analisis wacana biasa. Analisis wacana kritis menggalis alasan mengapa sebuah wacana memiliki struktur tertentu, yang pada akhirnya akan berujung pada analisis hubungan sosial antara pihak-pihak yang tercakup dalam wacana tersebut. Tujuan analisis wacana kritis adalah menjelaskan dimensi linguistik kewacanaan fenomena sosial dan kultural dan proses perubahan dalam modernitas terkini (Jørgensen \& Phillips, 2007, p. 116).

\section{Isu-isu mengenai Papua} merupakan isu yang masih berlarut-larut sampai sekarang. Permasalahan seperti kekerasan aparat terhadap masyarakat Papua sering kali diabaikan oleh publik karena keterbatasan informasi yang sampai ke luar Papua. Sehingga masyarakat Indonesia di luar Papua sering kali tidak tahu kondisi sebenarnya yang sedang terjadi di sana. Hal tersebut disebabkan oleh pembatasan infomasi di Papua. Pembatasan tersebut disebut oleh sebagian kalangan disebabkan oleh Papua yang "dianaktirikan" oleh pihak-pihak yang mempunyai kuasa.

Selain isu kekerasan, Papua juga sering dihadirkan media dengan isu separatisme. Kelompok kriminal bersenjata sering kali diidentikan dengan masyarakat Papua secara umum. Padahal, tidak semua masyarakat Papua merupakan kelompok kriminal bersenjata. Namun, masih banyak media yang memberitakan tentang kekerasan yang terjadi kepada masyarakat Papua. Maka dari itu peneliti ingin melihat bagaimana kekerasan di Papua diberitakan oleh media. Dalam hal ini peneliti ingin melihat pemberitaan kekerasan di Papua dalam media Tirto.id dalam berita yang berjudul "Merekam Kekerasan di Papua”.

Berdasarkan uraian di atas, rumusan masalah dalam penelitian ini adalah bagaimana struktur dalam berita Tirto.id yang berjudul "Merekam Kekerasan di Papua” menurut pendekatan teori model Teun A. Van Dijk. Adapun tujuan penelitian ini adalah untuk mengetahui analisis wacana kritis model Teun A. Van Dijk terhadap berita Tirto.di yang berjudul "Merekam Kekerasan di Papua”.

Secara teoretis, manfaat penelitian ini diharapkan akan menjadi referensi dan 
bahan pembelajaran analisis wacana kritis model Teun A. Van Dijk bagi para pembaca khususnya jurusan Bahasa dan Sastra Indonesia. Manfaat praktis penelitian ini juga diharapkan dapat memberikan manfaat kepada para praktisi linguistik. Selain itu, hasil penelitian ini diharapkan memiliki manfaat untuk seluruh peneliti dan pembaca dalam menambah wawasan serta pengetahuan mengenai analisis wacana krtis model Teun A. Van Dijk.

\section{METODE PENELITIAN}

Metode yang digunakan dalam penelitian ini adalah penelitian kualitatif. Bogdan dan Taylor (dalam Santoso, 2012, p. 4) menjelaskan menjelaskan metode kualitatif adalah metode yang menghasilkan sebuah deskripsi dari kata kata tertulis atau lisan dari orang-orang atau perilaku yang dapat dilihat. Maka dari itu, penelitian ini merupakan penjelasan dari sebuah fenomena menggunakan kata-kata dan tidak menggunakan angka-angka.

Objek penelitian ini adalah kata, frasa, kalimat atau wacana yang ada dalam berita Tirto.id yang berjudul "Merekam Kekerasan di Papua". Teknik pengumpulan data dalam penelitian ini menggunakan teknik simak dan teknik catat. Teknik simak adalah teknik untuk memperoleh data penelitian dengan menyimak suatu fenomena penggunaan bahasa. Mahsun (dalam Santoso, 2012, p. 5) menyatakan bahwa teknik catat adalah mencatat data-data yang relevan untuk sebuah penelitian. Dalam artikel ini, penulis berperan sebagi instrumen penelitian. Pengumpulan data bahasa dilakukan penulis dengan cara menyimak berita yang ada dalam Tirto.id yang berjudul "Merekam Kekerasan di Papua".

Teknis analisis data dalam penelitian ini menggunakan model Miles da Huberman. Miles dan Huberman (Sugiyono dalam Mulyani et al., 2020) mengatakan bahwa data kualitatif dilakukan secara interaktif dan berlangsung secara terus menerus sampai tuntas, sehingga datanya sudah jenuh (Sugiyono dalam Mulyani et al., 2020). Kegiatan peneliti dalam analisis data adalah mereduksi data, menyajikan data, menarik kesimpulan data dan verifikasi.

Penelitian ini menggunakan analisis wacana kritis untuk mengkaji dan membongkar ideologi yang ada dalam berita Tirto.id yang berjudul "Merekam Kekerasan di Papua”. Analisis wacana kritis menurut Darma (2009:49) adalah sebuah upaya atau proses untuk memberi 
penjelasan dari sebuah teks (realitas sosial) yang akan atau sedang dikaji oleh seseorang atau keompok dominan yang kecenderungannya mempunyai tujuan tertentu untuk memperoleh apa yang diinginkan.

\section{HASIL DAN PEMBAHASAN}

\section{Analisis Struktur Makro (Tematik)}

Pada anlaisis struktur makro, poin wacana yang diamati adalah topik atau tema yang merupakan inti gagasan berita yang ingin disampaikan penulis berita kepada publik. Tema yang diangkat dalam berita ini adalah kekerasan aparat terhadap masyarakat Papua. Tema ini diangkat secara jelas oleh penulis berita dengan memaparkan beberapa kasus kekerasan yang pernah terjadi.

\section{Analisis Super Struktur (Skematik)}

Tema atau topik berita "Merekam Kekerasan di Papua", didukung dengan proses pembentukan alur informasi berita yang skematik yaitu bagaimana bagian dan urutan berita diskemakan dalam bentuk teks berita yang utuh (Humaira, 2018). Penulis berita memulai wacananya dengan memaparkan pendapat ahli tentang penerimaan informasi berita tentang Papua yang tidak bisa mengandalkan hanya satu ada referensi berita saja. Perlu menggunakan prinsip jurnalistik untuk mengolah informasi papua dan membaca banyak referensi agar informasi yang diterima semakin kredibel. Penulis juga menggambarkan informasi mengenai papua hanya didapat melalui aparat. Pernyataan tersebut membentuk pernyataan bahwa informasi tidak boleh hanya mengandalkan informasi dari mereka. Pernyataan tersebut disambung dengan paragraf yang menjelaskan tentang pembatasan informasi ke papua.

Pada bagian pertengah dari tubuh berita, penulis berita memaparkan kasuskasus kekerasan yang dialami oleh masyarakat papua. Dimulai dari pemaparan kasus pekerja proyek pembangunan jalan Trans Papua yang meninggal. Penulis menggambarkan informasi pekerja yang meninggal belum bisa dipastikan jumlahnya, ada beberapa sumber yang menyebutkan angka kematian yang berbeda.

Kemudian penulis berita memuat sebuah segmen yang memiliki sub judul sendiri yaang berjudul "Kala Tentara Merekam Aksi Kekerasan Koleganya.” Dalam segmen tersebut penulis berita 
Pemberitaan Tirto.id tentang Kekerasan...

memaparkan kasus kekerasan yang dilakukan oleh aparat kepada dua orang petani bernama Kiwo dan Gire. Penulis berita menggambarkan penyiksaan yang dilakukan oleh aparat dengan cukup detail.

Penulis berita kemudian membuat segmen yang berbeda lagi dengan sub judul; "Merekam juga Riskan". Dalam segmen tersebut penulis berita menjelaskan kembali tentang kekerasan aparat kepada masyarakat papua. Kali ini aparat polisi yang merespon aksi massa masyarakat papua dengan menembakan peluru tajam ke massa kerusuhan. Hal tersebut kemudian diakui oleh Kapolda Papua yang mengatakan bahwa anak buahnya telah melanggar prosedur standar pengendalian massa.

Pada bagian akhir berita, penulis berita mengutip perkataan Andreas Harsono yang menjelaskan tentang kerjakerja jurnalisme yang dibatasi, sedangkan warga masih mendapat perlakuan represi. Kemudian penulis berita melanjurkan perkataan Andreas Harsono yang mengajak pembaca untuk bersama menembus lapisan propaganda, pelintir informasi dan pembelaan dari warga sendiri. Kalimat tersebut seperti sebuah ajakan untuk melawan ketidakadilan yang dalam hal ini merupakan pembatasan informasi yang ada di Papua.

\section{Analisi Struktur Mikro}

\section{Analisis Semantik}

Semantik dalam model analisis van Dijk dikategorikan sebagai makna lokal. Maksudnya adalah makna yng muncul merupakan hasil dari hubungan antar kalimat dan antar proposisi yang membangun makna tertentu dalam suatu konstruksi wacana (Suciartini, 2017). Analisis semantik wacana "Merekam Kekerasan di Papua" akan dipaparkan dalam bagian latar, detail, maksud, dan praanggapan.

Latar dalam analisis semantik model van Dijk adalah elemen wacana yang dapat dijadikan sebagai alasan pembenar gagasan yang diajukan dalam sebuah wacana. Latar dapat digunakan untuk membongkar apa maksud yang ingin disampaikan wartawan.

"Pembunuhan puluhan pekerja proyek pembangunan Jalan Trans Papua Sesi Distrik Yall Kabupaten Ndug, pada 2 Desember kemarin adalah salah satu contohnya."

Dari kutipan wacana di atas menunjukan bahwa penulis berita berusaha membentuk sebuah wacana yang menghadirkan kasus-kasus kekerasan yang menimpa masyarakat Papua. 
Nur Wahyudi, Dadang S Anshori, Jatmika Nurhadi...

Kutipan mengenai kekerasan Papua yang lain dapat dilihat di bawah ini.

"Analis Andreas Harsono bersama tim Human Right Watch menunjukan video itu merekam penyiksaan terhadap dua petani, Tunaliwor Kiwa dan Telangga Gire, di Desa Yogorini, Distrik Tingginambut, Kabupaten Puncak Jaya pada 30 Mei 2010."

Dari kedua kutipan di atas dapat ditarik sebuah kesimpulan bahwa wacana "Merekam Kekerasan di Papua" dilatarbelakangi oleh kekerasan yang diderita oleh masyarakat Papua. Hal tersebut ditunjukan dengan penulis berita memaparkan berbagai kasus kekerasan yang pernah terjadi kemudian membentuknya menjadi satu kesatuan berita.

Detil berhubungan dengan kontrol informasi yang dihadirkan oleh penulis berita (Yana, 2016). Penulis berita akan berusaha menampilkan secara rinci atau bahkan berlebihan informasi yang menguntungkan dirinya atau membuat citra dirinya menjadi lebih baik. Bagian detail ini juga dapat menyudutkan pihak lain dengan menggambarkan sisi negatif yang dilakukan. Hal tersebut ditunjukan oleh wacana "Merekam Kekerasan di Papua" yang banyak sekali menjelaskan secara rinci peristiwa-peristiwa kekerasan yang dilakukan oleh aparat terhadap masyarakat Papua.

"Dalam video tersebut, sekelompok tentara menginterogasi Kiwa dan Gire, menanyai keberadaan senjata. Kiwa menjawab tidak tahu soal itu. Lalu, para tentara menendang wajah dan dada Kiwo. Mereka juga menyundut wajah Kiwo dengan rokok dan mendekatkan kayu berapi ke penisnya. "Bakar penisnya! Bakar penisnya!" para tentara bersahutan. Kemudian, tentara menaruh pisau di leher Gire, saat api mendekati penis, Kiwo berteriak, namun, tentara menyodorkan senjata api ke mulut Kiwo dan berkata "Diam. Diam. Kutembak. Kutembak mulutmu."

Dari kutipan di atas penulis berita menjelaskan peristiwa kekerasan yang menimpa dua petani Papua dengan sangat rinci. Tindakan-tindakan aparat yang menyiksa Kiwa dab Gire digambarkan secara gamblang dengan bahasa yang lugas. Hal tersebut menciptakan kondisi pembaca yang akan mengecap aparat adalah orang-orang kasar yang kejam. Kutipan lain yang menunjukan detail penyiksaan masyarakat Papua dapat dilihat di bawah ini.

"Pada saat itu juga beredar video lain yang merekam tentara Indonesia menginterogasi sambil memukuli, bahkan dengan helm dan menendangi orang-orang Papua." 
Dari kutipan berita di atas, terlihat jelas bahwa penulis berita menjelaskan secara rinci peristiwa yang terjadi dengan menuliskan "bahkan dengan helm dan menendangi orang-orang Papua”. Detil ini dapat semakin memberikan gambaran besar terhadap pembaca bagaimana aparat bertindak terhadap orang-orang Papua.

Penggambaran aparat yang kasar juga dibentuk melalui kalimat-kalimat yang menjelaskan peristiwa secara kronologis atau urutan-urutan kejadian. Kalimat ini berusaha membentuk mental pembaca yang akan ikut tidak menyukai aparat karena detail-detail yang dihadirkan.

"Cosmos menyatakan mendapatkan informasi keberadaan senjata AK-47 dan Mauser di suatu tempat di desa Garage, Puncak Jaya. Saat mencapai desa tersebut Cosmos dan timnya memisahkan penduduk desa berdasarkan jenis kelamin dan menginterogasi mereka satu persatu. Saat tidak mendapatkan jawaban yang diinginkan, Cosmos dan tentara lain menendang dan memukuli penduduk desa.

Kutipan berita di atas menunjukan detail-detail yang membentuk sebuah urutan peristiwa. Dengan mengurutkan peristiwa tersebut, pembaca akan menyimpulkan bahwa aparat akan menjadi semena-mena dan kasar apabila mereka tidak menemukan senjata yang menurut kabar ada di desa tersebut.
Poin selanjutnya yang menjadi bagian dari analisis semantik van Dijk adalah maksud. Maksud dalam hal ini melihat apakah wacana itu disampaikan secara eksplisit atau tidak. Secara umum sebuah informasi yang merugikan kelompok penulis berita akan disampaikan secara tersamar atau implisit.

Dalam wacana "Merekam Kekerasan di Papua", penulis berita menggambarkan bahwa dalam memahami isu-isu Papua harus menggunakan prinsipprinsip jurnalisme. Kemudian dilanjutkan dengan menjelaskan bahwa akses informasi ke Papua dibatasi yang mengakibatkan media sangat bergantung pada informasi dari aparat keamanan dan militer. Yang hal tersebut dianggap sebuah informasi yang tidak kredibel jika hanya bersumber pada satu rujukan saja. Paragraf awal itu bermaksud menggambarkan bahwa biasanya beritaberita di Papua itu tidak damai-damai saja yang semua orang kira. Tetapi ada banyak kekerasan di dalamnya.

Berita tersebut dilanjutkan dengan menunjukan contoh pembunuhan di Papua. Pada awal-awal berita penulis lebih memfokuskan tulisannya dengan peristiwa yang ingin diperlihatkan, yaitu peristiwa pembunuhan, dengan tidak menjelaskan siapa pelaku pembunuhan 
Nur Wahyudi, Dadang S Anshori, Jatmika Nurhadi...

tersebut dan kenapa pelaku membunuh orang-orang Papua yang menjadi pekerja proyek pembangunan Jalan Trans Papua.

"Pembunuhan puluhan pekerja proyek pembangunan Jalan Trans Papua sesi Distrik Yall Kabupaten Nduga pada 2 Desember kemarin adalah salah satu contohnya. PT Istaka Karya perusahaan yang bertanggung jawab atas pekerja itu belum bisa memastikan berapa jumlah pekerja yang menjadi korban”

Penulis berita sekali menunjukan maksud tersirat pada kalimatnya bahwa informasi yang didapatkan dari aparat tidak diperlukan karena seperti di awal kalimat bahwa penulis menggambarkan bahwa informasi dari aparat kurang kredibel. Sehingga penulis berita menggambarkannya dengan kalimat memprioritaskan informasi bersumber dari masyarakat.

"Victor mengatakan Jubi berusaha mengorek informasi dari orang-orang sipil, pejabat pemerintah, atau gereja. Kata Victor "Jarang juga kami menggunakan informasi dari polisi atau tentara. Kami prioritaskan informasi bersumber dari masyarakat."

Penulis berita memaparkan contoh-contoh kasus kekerasan aparat terhadap orang-orang Papua dengan sangat eksplisit. Penulis menggunakan kalimat aktif yang menunjukan subjek dan objek dalam peristiwa kekerasan.
"Victor ingat pada 2010 dia memperoleh video yang memuat penyiksaan aparat militer Indonesia terhadap orang Papua."

"Namun, kesaksian para korban dan foto milik Dewan Adar Panial menunjukkan selongsong peluru yang diduga ditemukan di lokasi penembakkan menguatkan dugaan bahwa polisi telah menggunakan peluru tajam. (Foto ini kemudian dimuat di situs web Human Rights Watch) sementara jenazah korban tidak diotopsi. Kapolda Papua meyatakan anak buahnya telah melanggar prosedur standar pengendalian massa. Ujungnya, sembilan personel polisi dinyatakan bersalah tapi tidak dipidanakan; hanya menerima "hukuman administratif.",

Pembahasan selanjutnya dari analisis semantik Van Dijk adalah praanggapan. Praanggapan merupakan pernyataan yang digunakan untuk membentuk makna suatu wacana dengan memberikan premis yang dipercaya kebenarannya oleh publik yang kemudian menjadi dasar untuk mendukung gagasan tertentu.

"Ada 24 Orang yang dibunuh. Dua lain melarikan diri." Ujar Gwijangge. Victor Mambor, jurnalis Tabloid Jubi yang menulis berita tersebut, berkata kepada Tirto bahwa wartawan-wartawan Jubi belum bisa mendatangi lokasi guna mengecek kebenaran informasi pembunuhan para pekerja tersebut”.

“Kita baru bisa konfirmasi ke Wakil Ketua DPRD Nduga [Alimin Gwijangge]. Problmnya, dia juga 
Pemberitaan Tirto.id tentang Kekerasan...

tidak berada di tempat waktu kejadian. Jadi saya juga tanya apakah dibunuhnya itu ditembak atau diapakan, dia tidak tahu karena tempat di jauh dari lokasi, "ujar Victor.

Kedua kutipan tersebut memaparkan tentang korban yang tewas dalam proyek pembangunan jalan. Penulis berita menekankan pada kalimat yang menggunakan kata pembunuhan dan sejenisnya untuk memberikan gambaran kengerian kepada pembaca. Praanggapan dalam kutipan tersebut ditunjukan dengan memberikan pernyataan bahwa wartawan Jubi belum mendatangi lokasi untuk melakukan validasi dari informasi yang sebelumnya sudah diterima. Praanggapan pada kutipan kedua ditunjukan dari pernyataan Victor bahwa yang masih bertanya bagaimana para korban bisa tewas, apakah ditembak atau diapakan?

Selain perihal jumlah korban tewas para pekerja proyek jalan. Praanggapan ditunjukan dari wacana tentang warga yang menyerang sebuah kantor karena karyawannya tidak mau meminjamkan mobil untuk membawa seorang warga yang baru saja tenggelam. Pernyataan karyawan perusahaan menolak meminjamkan mobil merupakan praanggapan yang digunakan penulis berita. Karena peristiwa penolakan tersebut tidak dijelaskan lebih rinci. Penulis berita hanya berfokus pada peristiwa penolakannya saja yang kemudian disambung dengan memberitahu bahwa mobil tersebut digunakan untuk membawa seorang warga yang tenggelam.

“Warga menyerang kantor itu lantaran para karyawan perusahaan menolak meminjamkan mobil untuk membawa seorang warga yang baru saja tenggelam (warga ini kemudian meninggal)",

\section{Analisis Sintaksis}

Pada analisis sintaksis hal yang akan dibahas adalah bentuk kalimat. Bentuk kalimat merupakan segi sintaksis yang berhubungan dengan cara berpikir logis, yaitu prinsip kausalitas atau sebab akibat. Terdapat unsur subjek dan predikat dalam setiap kalimat. Bentuk kalimat ini menentukan apakah subjek digambarkan secara jelas atau tersirat.

Dalam wacana "Merekam Kekerasan di Papua", penulis berita menampilkan aktor-aktor sosial secara jelas. Dalam beberapa kalimat, penulis hanya fokus untuk menampilkan korban yang menjadi objek kekerasan. Hal tersebut dibuat untuk menggambarkan masyarakat Papua yang tertindas dan diperlakukan tidak adil. Beberapa kalimat 
Nur Wahyudi, Dadang S Anshori, Jatmika Nurhadi...

lain menunjukan pelaku peristiwa kekerasam dengan jelas. Seperti menunjukan kelompok besar aparat yang menjadi anggota kelompok tersebut dan beberapa kali menunjukan secara detail nama pelaku kekerasan terhadap masyarakat Papua.

“analisis Andreas Harsono bersama tim Human Rgihts Watch menunjukan video itu merekam penyiksaan terhadap dua petani, Tunaliwor kiwo dan Telangga Gire, di Desia Yogorini, Distrik Tingginambut, Kabupaten Puncak Jaya, pada 30 Mei 2010.

Bentuk kalimat yang dipakai merupakan kalimat aktif, sehingga pembaca akan dengan mudah menangkap siapa yang sedang diperlakukan bagaimana. Unsur kausalitas beberapa kali terlihat untuk menunjukan urutan waktu kejadian yang memakai unsur sebab akibat.

“Kapolda Papua menyatakan anak buahnya telah melanggar prosedur standar pengendalian massa. Ujungnya, sembilan personel polisi dinyatakan bersalah tapi tidak dipidanakan; hanya menerima "hukuman administratif"

Unsur lain yang dibahas dari analisis sintaksis adalah koherensi. Koherensi adalah hubungan pertalian antar kata, proposisi atau kalimat. Dua kalimat atau proposisi yang menggambarkan fakta yang berbeda dapat dihubungkan dengan memakai koherensi. Shingga fakta yang tidak berhubungan sekalipun dapat menjadi berhubungan ketika penulis berita melakukannya.

"PT Istaka Karya, perusahaan yang bertanggung jawab atas pekerja itu, belum bisa memastikan berapa jumlah pekerja yang menjadi korban. Sedangkan media yang berpusat di Jakarta memberitakan sebanyak 31 orang menjadi korban.

Dari kutipan wacana di atas, kata "sedangkan" menjadi sebuah penghubung yang menunjukan adanya sebuah perbandingan. Perbandingan tersebut diciptakan untuk menyudutkan PT Istaka Karya yang belum bisa memastikan jumlah pekerja yang menjadi korban. Sedangkan di pihak lain ada media yang mampu memberitakan jumlah korban. Selain menggunakan kata untuk membandingkan, penulis berita juga menggunakan kata "namun" untuk menunjukan sebuah keadaan yang jomplang dengan keadaan sebelumnya atau keadaan yang bertentangan.

"kemudian, tentara menaruh pisau di leher Gire. Saat api mendekati penis, Kiwo berteriak. Namun, tentara menyodorkan senjata api ke mulut Kiwo dan berkata, "Diam. Diam. Kutembak. Kutembak mulutmu”.

“pihak kepolisian semula mengklaim menggunakan hanya peluru karet. Namun, kesaksian para korban dan foto milik Dewan Adar Paniai menunjukkan selongsong peluru yang 
diduga ditemukan di lokasi penembakan menguatkan dugaan bahwa polisi telah menggunakan peluru tajam.

Pada kutipan wacana di atas, penulis berita menggunakan "namun" untuk mempertentangkan sebuah keadaan. Kutipan pertama menunjukan sebuah keadaan Kiwo yang berteriak sebagai tanda tidak ingin disiksa lagi tetapi aparat tersebut malah menyodorkan senjata api dan mengancamnya secara verbal. Sifat koherensi kalimat tersebut dipakai untuk menunjukan aparat yang semena-mena kepada masyarakat Papua yang tidak berdaya dan tidak memiliki kemampuan untuk melawan.

Sama halnya dengan kutipan pertama, kutipan kedua juga menunjukan sebuah keadaan yang tumpang tindih antara kalimat satu dengan kalimat selanjutnya. Dalam kutipan tersebut menggambarkan aparat yang mengklaim bahwa mereka menggunakan peluru karet untuk mengamankan warga yang ricuh. Tetapi pernyataan tersebut berbanding terbalik dengan kalimat selanjutnya yang menunjukan kesaksian warga yang melihat selongsong peluru. Hal tersebut dapat dari penggunaan kata "namun" untuk membuat dua kalimat itu koheren. Kalimat pernyataan aparat kepolisian ditempatkan di awal digunakan untuk membuat pernyataan tersebut seolah-olah hanya bualan yang kemudian ditentangkan dengan pernyataan dari kesaksian warga.

Aspek selanjutnya yang dibahas dari analisis sintaksis adalah kata ganti. Kata ganti merupakan elemen untuk memanipulasi bahasa dengan membuat suatu komunitas imajinatif. Kata ganti adalah alat yang dipakai penulis berita untuk menunjukan dimana posisi seseorang dalam wacana.

Dalam berita "Merekam Kekerasan di Papua" penulis berita terlihat menggambarkan dua buah kelompok yang bertentangan, yaitu kelompok masyarakat Papua dan kelompok militer dan polisi. Hal tersebut dapat dilihat dari penggunaaan kata "orang Papua" dan "aparat militer" pada kutipan di bawah ini.

"Victor ingat pada 2010 dia memperoleh video yang mетиаt penyiksaan aparat militer Indonesia terhadap orang Papua”

Dari kutipan wacana tersebut terlihat penulis berita membuat sebuah kelompok besar antara orang Papua dan aparat militer secara umum dan luas. Padahal tentu saja tidak semua militer Indonesia terlibat dalam kasus kekerasan terhadap masyarakat Papua. Begitupun 
Nur Wahyudi, Dadang S Anshori, Jatmika Nurhadi...

sebaliknya dengan masyarakat Papua yang tidak semuanya mengalami represi atau kekerasan. Kalimat yang menggunakan strategi serupa dapat dilihat pada kutipan di bawah ini.

"Pada saat itu juga beredar video lain yang merekam tentara Indonesia menginterogasi sambil memukuli, bahkan dengan helm dan menendangi orang-orang papua."

\section{Analisis Stilistik}

Pusat stilistik adalah gaya, yaitu cara seorang pembicara atau penulis untuk menyatakan maksudnya dengan menggunakan bahasa sebagai sarana. Dalam analisis ini poin pembahasan akan berfokus pada leksikon. Leksikon menandakan bagaimana seseorang melakukan pemilihan kata atas berbagai kemungkinan kata yang ada.

"Laporan human rights watch pada 2015 yang relevan hingga kini menggambarkan akses informasi mengenai Papua dibatasi”

Penulis berita menggunakan diksi dibatasi untuk menggambarkan akses informasi di Papua. Dari kata tersebut menunjukan sebuah kesengajaan oleh pihak tertentu untuk membatas akses informasi di Papua. Selain itu, penulis berita didapati menggunakan diksi yang mempunyai intonasi yang menggambarkan situasi yang tidak wajar. Hal tersebut dapat dilihat pada kutipan di bawah ini.

"Kiwo dan Gire dikerangkeng oleh anggota kesatuan tersebut."

Penulis berita lebih memilih menggunakan kata kerangkeng dari pada kata lain yang mengandung makna yang sama atau setidaknya sama. Kata kerangkeng terdengar lebih dramatis daripada dikurung atau dipenjara.

\section{Analisis Retoris}

Analisis retoris berkaitan dengan bagaimana cara wartawan menyampaikan pendapatnya terhadap sebuah berita. Retoris mempunyai fungsi persuasif dan berhubungan erat dengan bagaimana pesan ini ingin disampaikan kepada khalayak. Dalam analisis ini terbagi lagi menjadi dua bagian yaitu analisis grafis dan metafora.

Grafis merupakan bagian yang dibuat oleh penulsi berita untuk membuat pembaca menaruh perhatian lebih pada bagian tersebut. Bagian grafis tersebut dapat membentuk persepsi pembaca sesuai yang diinginkan penulis. Bagian 
Pemberitaan Tirto.id tentang Kekerasan...

grafis ini juga bisa dipakai untuk menekankan sebuah ideologi tertentu dengan menekankan wacana melalui penulisan grafis tertentu.

Pada bagian awal wacana "Merekam Kekerasan di Papua", penulis berita menyimpan sebuah gambar yang menunjukan burung garuda dan burung cenderawasih yang sedang berkelahi. Burung garuda merepresentasikan negara Indonesia karena burung garuda menjadi lambang negara Indonesia, sedangkan burung cenderawasih merepresentasikan Papua karena burung cenderawasih merupakan burung endemik tanah Papua. Secara tidak langsung penulis ingin menyampaikan bahwa Papua sedang "berkelahi” dengan Indonesia.

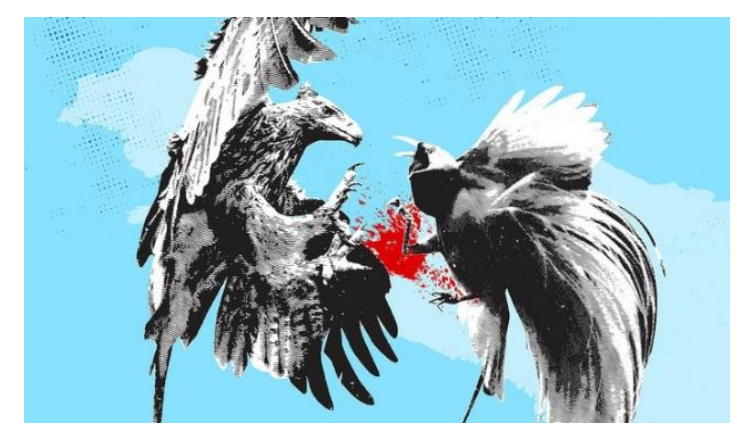

Metafora adalah kiasan atau ingkapan yang dimaksudkan sebagai bumbu dari suatu berita untuk membuat wacana tersebut lebih dramatis. Metafora

dipakai oleh penulis berita secara strategis sebagai landasan berpikir, alasan pembenar atas pendapat atau gagasan tententu kepada pembaca (Yana, 2016)

"Andreas Harsono berkata kepada Tirto, dalam situasi Papua ketika kerja-kerja jurnalisme dibatasi dan warga direpresi, sementara peristiwa penembakan terjadi sporadis, "korban pertama adalah kebenaran." Ia berkata untuk mengabarkan peristiwa konflik di Papua, "kita harus menmbus lapisan propaganda, pelintir informasi, dan pembelaan dari warga sendiri."

Penulis berita menggunakan ungkapan korban pertama adalah kebenaran, yang mengisyaratkan bahwa kebenaran sudah tidak ada di tanah Papua. Kalimat tersebut dibuat untuk membuat wacana semakin dramatis untuk dibaca oleh publik. Penulis membuat kebenaran sebagai objek yang menjadi korban pertama menjadi sebuah simpulan yang akan menggugah empati publik.

\section{SIMPULAN}

Berdasarkan hasil analisis wacana kritis model Teun A. Van Dijk pada berita Tirto.id yang bberjudul "Merekam Kekerasan di Papua" dapat disimpulkan bahwa tema yang ada dalam berita tersebut adalah kekerasan yang terjadi terhadap masyarakat Papua. Alur yang dibentuk untuk membuat berita tersebut menggunakan pembukaan yang 
memaparkan tentang situasi umum yang ada di Papua dan contoh kasus pembunuhan, kemudian dilanjutkan dengan segmen-segmen khusus yang memuat kasus-kasus kekerasan lainnya yang menimpa masyarakat Papua. Struktur mikro pada berita kekerasan di Papua ditemukan seluruh unsur semantik, sintaksis, leksikon dan stilistika.

\section{DAFTAR PUSTAKA}

Darma, Y. A. (2009). Analisis wacana kritis. Yrama Widya bekerja sama dengan Jurusan Pendididikan Bahasa dan Sastra Indonesia (FPBS UPI). https://books.google.co.id/books?i $\mathrm{d}=$ S63dSAAACAAJ

Eriyanto. (2011). Analisis Wacana ; Pengantar Analisis Teks Media: Komunikasi. LKiS Yogyakarta. https://books.google.co.id/books?i $\mathrm{d}=68 \mathrm{dVDwAAQBAJ}$

Humaira, H. W. (2018). Analisis Wacana Kritis (AWK) Model Teun A. Van Dijk pada Pemberitaan Surat Kabar Republika. Literasi, 2(1), 32-40.

https://jurnal.unigal.ac.id/index.ph $\mathrm{p} /$ literasi/article/view/951

Jørgensen, M., \& Phillips, L. J. (2007). Analisis wacana: teori \& metode. Pustaka Pelajar. https://books.google.co.id/books?i $\mathrm{d}=\mathrm{uPWkQwAACAAJ}$

Kridalaksana, H. (2013). Kamus Linguistik (Edisi Keempat). Gramedia Pustaka Utama. https://books.google.co.id/books?i $\mathrm{d}=\mathrm{gKNLDwAAQBAJ}$

Lukman. (2006). linguistik indonesia. Yayasan Obor Indonesia. https://books.google.co.id/books?i $\mathrm{d}=1 \mathrm{C} 9-4 \mathrm{t} 30$-esC

Mulyani, M., Ratnawati, I. I., Balikpapan, U., Balikpapan, U., Balikpapan, U., \& Ujaran, K. (2020). KILIR LIDAH PRODUKSI UJARAN ISYANA SARASVATI PADA VIDEO KOMPILASI YOUTUBE TINJAUAN PSIKOLINGUSTIK. Jurnal Basataka, 3(2), 118-127.

Santoso, S. (2012). Permainan bahasa pada stiker sepeda motor. Universitas Muhammadiyah Surakarta.

Suciartini, N. N. A. (2017). ANALISIS WACANA KRITIS "SEMUA KARENA AHOK" PROGRAM MATA NAJWA METRO TV. Aksara, 29(2), 267-282.

Yana, D. (2016). Critical Discourse Analysis (Cda) of Sindo Newspaper (Cda a Model of Van Dijk). Cahaya Pendidikan, 1(1). https://doi.org/10.33373/chypend. v1i1.373 